Volume. 5 Number. 2

Period: July - December 2021; page 55-61

p-ISSN : 2580-1112; e-ISSN : 2655-6669

Copyrighr@2020

The author owns the copyright of this article

journal homepage: https://ejournal.akperfatmawati.ac.id

DOI : 10.46749/iiko.v5i2.75
Jurnal IImiah Keperawatan Orthopedi (JIKO)

Article history:

Received: October 22, 2021

Revised: February 11, 2022

Accepted: February 13, 2022

\title{
The Problems Affecting the Implementation of Posyandu Program: A Literature Review
}

\author{
Tirta Adikusuma Suparto ${ }^{1}$, Nadia Nur Azizah², Septian Andriyani ${ }^{3}$, \\ Asih Purwandari Wahyoe Puspita ${ }^{4}$, Yanti Hermayanti ${ }^{5}$ \\ ${ }^{1234}$ Departemen Keperawatan, Fakultas Pendidikan Olahraga dan Kesehatan, \\ Universitas Pendidikan Indonesia, Bandung, Indonesia \\ ${ }^{5}$ Departemen Keperawatan Maternitas, Fakultas Keperawatan Universitas Padjadjaran, \\ Bandung, Indonesia \\ E-mail: tirta.adikusuma.123@upi.edu
}

\begin{abstract}
Integrated Health Post for Child Center/Pos Pelayanan Terpadu (Posyandu) is a form of community-based health program carried out by, from, and along with the community to empower and provide facilities for the community to obtain health services for mothers, babies, and toddlers. Posyandu activities include: KIA, family planning, immunization, nutrition, diarrhea prevention. Posyandu in Indonesia still faced several problems. This study aimed at investigating the problems that affect the implementation of Posyandu program and actions to improve Posyandu program services. The method used in this study was literature review. The literatures used in this study were the search results through national and international journals. National includes google scholar [https://scholar.google.co.id/] and international includes Pubmed [https://www.ncbi.nlm.nih.gov/pubmed] with the keyword "Problems and Posyandu Program" published in 2016-2020. Based on the search results, 8 national and 2 international articles related to the topic and in accordance with the inclusion and exclusion criteria were found. The results of 10 literature reviews show there are several fundamental problems of Posyandu program in Indonesia, namely: 1) the low role of Posyandu cadres; 2) the lack of understanding on the benefit of Posyandu program; 3) The lack of participation in Posyandu activities; 4) The lack of facilities and infrastructure for Posyandu activities; and 5) the lack of cross-program and cross-sector cooperation. In addition, there are 5 actions needed to solve the problems. The first action is to conduct a training program for Posyandu cadres. The second one is to conduct regular outreach at Posyandu for mothers and families by trained cadres. The third one is to improve the facilities and infrastructure in Posyandu. The fourth one is to provide both material and immaterial incentives for an active Posyandu's cadre. Lastly, the fifth action is to increase advocacy efforts to related parties. Posyandu program are still facing problems affecting its implementation. Therefore, the posyandu revitalization actions are needed. The main key lies in increasing cadres' capacity through training.
\end{abstract}

Keywords: Posyandu Program, Problems, Implementation

\section{Introduction}

Health service facility is a place to administer the government, regional government and/or the community. One of the health service facilities in Indonesia is the Puskesmas. Puskesmas is a health service facility that organizes public health efforts and first-level 
individual health efforts, with a greater emphasis on promotive and preventive efforts, to achieve the highest public health status in its working area (Kemenkes, 2019).

One of the programs Puskesmas priority to mother and child is the Posyandu Program. Posyandu is a form of Community-Based Health Efforts/ Usaha Kesehatan Berbasis Masyarakat (UKBM) carried out by, from and with the community to empower and provide facilities for the community to obtain health services for mothers, babies and toddlers (Kemenkes RI, 2011). UKBM are a form of health service facilities managed by the community. The success of this UKBM implementation cannot be separated from the role of the community as implementers and recipients of health services, so it is necessary to conduct a study on the use of UKBM by the community. Posyandu has several programs, namely maternal and child health, family planning, immunization, nutrition, and prevention or control of diarrhea.

Posyandu was founded in 1984, by three institutions at once, namely the Indonesian Ministry of Health, BKKBN, and the Ministry of Home Affairs. In the 1990s, Posyandu was growing very rapidly because the government issued the Minister of Home Affairs Instruction No. 9/1990 on improving the quality of Posyandu. But in 1999 there was a decline in the performance of the Posyandu program, responding to the decline in performance the government initiated the revitalization of the Posyandu. The revitalization effort was carried out with the issuance of a letter from the Minister of Home Affairs Number 411.3/1116/SJ dated June 13, 2001 regarding the revitalization of Posyandu, the main objectives of this revitalization include: carrying out regular and continuous Posyandu activities, achieving empowerment of figures and cadres, achieving Posyandu institutional development (Kurnia, 2019).

The number of Posyandu in Indonesia is quite large, namely: 283,370 institutions, consisting of several active Posyandu, namely 173,750/61.32\% Posyandu (Kemenkes RI, 2018). However, the quality of existing Posyandu is still lacking, Posyandu found several problems including completeness of facilities, inadequate skills of cadres, Puskesmas officers are often late and absent, many mothers do not bring toddlers to Posyandu regularly (Darajat, 2016; Sengkey \& Pangemanan, 2015).

Based on the results of a literature search, the study has not found any research that explores the problems that affect the implementation of the Posyandu program in a comprehensive manner. This study aimed at investigating the problems that affect the implementation of Posyandu program and actions to improve Posyandu program services.

\section{Method}

The research method used in this study is a literature review. This research was conducted in April 2020. The data collection process used the PRISMA ( Preferre Reporting Items for Systematic Rebiew and Meta-Analysis ). The journals used in the literature review were obtained through a database of international journal providers through Pubmed (website: https://www.ncbi.nlm.nih.gov/pubmed) and national journals through Google Scholar, and Garuda (website: https://scholar .google.co.id and http://garuda.ristekbrin.go.id). The researcher used the keywords "Posyandu Program", and "Posyandu Balita Program" and selected full text. 
The inclusion criteria used by researchers to limit the articles or journals used are limited to the search year from 2015 - 2020, the journal has the same title or content as the research objective, is full text, and has links to nursing and society. The exclusion criteria are (1) the article or journal has an incomplete structure; (2) in the form of a review or article review. From the results of the selection obtained 10 articles that match the criteria. Data analysis is done by compare, contrast, critize, and summarize. The research ethics applied in this literature are misconduct, not manipulating data, and checking for plagiarism using Turnitin software (http://www.turnitin.com).

\section{Result and Discussion}

Based on the results of the literature review, the authors found problems that affect the implementation of the Posyandu Program, as described as follows:

\section{Lack of funding sources for Posyandu activities and their solutions}

The funding source is one that is very important for the activities of Posyandu, because if no funding source Posyandu will not run properly. Because the activities of Posyandu in need of medicines, equipment and infrastructure to meet the in Posyandu. Based on several articles that have been reviewed, it proves that there is not enough funding for Posyandu activities.

Among them are research conducted by Agus and Yodi in 2018, which revealed that there are still many problems in implementing Posyandu, namely one of the problems is finance or disbursement of funds in rural areas due to the lack of priority given by the government or the local village head if it is not fixed immediately it will have an impact on decline in the implementation of Posyandu, supplies of medicines and equipment will be insufficient. Because the funds did not go well, research said that sometimes the Posyandu program was implemented using cadres' money, so that Posyandu would continue to run well (Setiawan \& Christiani, 2018) .

The source of funding is very important because if it does not work well between sectors such as delays in funding in the regional government, which causes the Posyandu program to run poorly due to insufficient availability of medicines, equipment and infrastructure that are still lacking and need to be updated (Setiawan \& Christiani, 2018).

The qualitative research conducted by Hariani in 2016 in the City of Sawahlunto shows that the funding for Posyandu activities is still lacking, namely from the operational support of the cadres which are lower in number. For this reason, it is hoped that cross-sectoral cooperation and support as well as the use of village funds and the need for community self-help support (Hariani \& Elytha, 2016) .

Problems that make funding sources not available properly are: poor funding provided by village heads to Posyandu, lack of collaboration between sectors, village heads do not prioritize Posyandu activities. Therefore, it is necessary to advocate to the Government about the importance of increasing the budget for Puskesmas in implementing Posyandu (Sengkey \& Pangemanan, 2015).

\section{The lack of the role of Posyandu cadres and their solutions}

The lack of a cadre role is one of the problems the Posyandu program is not running well. Based on several articles that have been reviewed, it is evident that periodic training for cadres is necessary. Among them is the research conducted by Dita, et al in Lamongan 
2018 said that they still have not implemented the Early Detection Program for Toddler Development properly, there are some cadres who do not know how to fill in KMS, or how to read KMS. This is due to the presence of cadres who did not attend training (Roykhana et al., 2018) .

The role of Posyandu cadres is a very important role in the Posyandu program. Several studies have shown that there is still a lack of cadres, due to a lack of motivation for the community to become Posyandu cadres. The lack of cadres has an impact on the less than optimal implementation of Posyandu. Therefore, the role of community nurses is needed to carry out regular cadre training.

\section{Lack of maternal participation in bringing children to Posyandu and their solutions}

The lack of participation of mothers in bringing their children to Posyandu is one of the problems that the implementation of the Posyandu program is not going well because the lack of awareness of mothers bringing their children to Posyandu causes a high prevalence of underweight, stunting and wasting, respectively $50.5 \%, 18.0 \%$, and $28.4 \%$. Due to the lack of mothers regarding the importance of nutritional status in children (Setiawan \& Christiani, 2018).

Based on several articles that have been reviewed, it proves that the participation of mothers in Posyandu activities in Indonesia is very low, including research conducted by Agus and Yodi 2018, the lack of participation of mothers in the Posyandu program because there are still many parents who are more concerned with finding additional jobs to add to the economy while for children's health is still less awareness.
As for Delta research in Pekanbaru 2017, the mother's lack of knowledge about the benefits of Posyandu is also one of the factors for mothers not bringing their children to Posyandu, apart from not understanding the benefits of Posyandu as well, mothers do not prioritize their children's health always under estimating their children's health problems, even to build immunity strong children need to be given vitamins, vaccines, and immunizations.

The consequences of mothers who never bring their children to Posyandu are lack of nutrition in children, stunting, and others (Aba, 2017). Therefore the role of public health nurses is needed to increase the participation of mothers in visiting Posyandu, and there is a need for counseling for mothers who do not know about the benefits of bringing their children to Posyandu .

From several studies, we can find that there are several problems that cause the low visits of mothers and children to Posyandu. Problem issues such as knowledge mother, distance between home and the location of Posyandu, facilities and infrastructure are inadequate, lack of information about Posyandu, economic and income, lack of awareness of the mother, and are not satisfied with the service Posyandu.

Parental education is one of the problems that affect children's visits to the Posyandu. Research conducted by Ayu, 2016 proves that mother's education affects toddlers' visits to Posyandu. Respondents who have higher education have a 9.4 times greater chance of visiting children under five to the Posyandu than respondents with low education.

Parents' knowledge about the benefits of the Posyandu program is a factor that affects the visit/participation of mothers coming to Posyandu. Research 
conducted by Isnain 2018 when a meeting was held regarding the Posyandu program, the community still did not know what the benefits of the Posyandu program were, many questions were asked about the benefits of the Posyandu program. After the community knows the benefits of the Posyandu program, mothers become enthusiastic about bringing their children to the Posyandu (Umasangaji, 2016).

\section{Other Problems and Solutions}

Other problems, such as inadequate facilities and infrastructure, lack of medicines, caused the Posyandu program to run poorly due to a lack of public interest in coming to Posyandu with poor or minimal facilities. Descriptive research by Anwar in 2016 at the Posyandu Dusun Gondang found the problems faced include inadequate facilities and infrastructure, insufficient medicines.

Therefore, the smooth implementation of activities at the Posyandu must be supported by supporting facilities and infrastructure, namely the place of activity (building, room or open area), tables and chairs, stationery, activity recording books, children's scales, height measurement meters, stethoscopes, blood pressure monitors. meters, simple laboratory equipment, thermometer, Kartu Menuju Sehat (KMS) (Darajat, 2016).

Research by Agus in 2018 found that there was still a lack of supplies of medicines and equipment. Research by Anwar 2016 that the facilities and infrastructure are not maximized. Santi's research in 2019 for Posyandu facilities that are not in accordance with needs. And Sriyatty's research 2015 needed to improve Posyandu facilities and infrastructure.

According to the studies above, it is proven that almost every Posyandu still has shortcomings in terms of facilities and infrastructure. Therefore, if we analyze it, the intervention that we must do is to improve the Posyandu facilities and infrastructure as well as to increase cross-programme and cross-sectoral collaboration. Because Posyandu is a collaborative program which means that each sector must be able to work well together.

As research conducted by Anwar in 2016, cross-sectoral support is still low, therefore a structured revitalization of the Posyandu organization is needed so that the implementation of Posyandu runs well and all parties can contribute properly.

\section{Conclusion}

From all comparisons of the ten articles, it is found that there are still many problems in the Posyandu program, namely: inadequate funding, low role and activity of Posyandu cadres, lack of knowledge of the benefits of the Posyandu program, lack of community participation in Posyandu activities, lack of facilities and infrastructure for Posyandu activities, and a lack of cooperation across programs and sectors. It is recommended to revitalize the Posyandu Program throughout Indonesia by:

1. Increasing the role of community nurses in carrying out Posyandu program activities and conducting Posyandu cadre training.

2. Increase the involvement of the organization so that it contributes a lot to the Posyandu program.

3. Enhancing cross-sector cooperation in the implementation of Posyandu program.

4. Increase the number of Posyandu cadres.

5. Increase community participation in the implementation of the Posyandu program. 
6. Improve the facilities and infrastructure needed by the Posyandu.

\section{References}

Aba, D. M. (2017). Gambaran Pendidikan, Persepsi Dan Sikap Ibu Yang Memiliki Anak Balita Tentang Program Posyandu Di Wilayah Kerja Puskesmas Melur Kelurahan Sukajadi. Menara Ilmu, XI(77), 18-24.

Cahyanti, A. (2016). Pelaksanaan Program Posyandu (Studi Kasus Di Desa Madu Kecamatan Mojosongo Kabupaten Boyolali. Retrieved from http://lib.unnes.ac.id/28458/

Darajat, A. H. (2016). Pelayanan Program Pokok Posyandu Di Desa Perspektif Sosiologi Keluarga. Jurnal Transliterasi, 4, $1-14$.

Dinkes. (2017). Jumlah Posyandu di Kota Bandung. Bandung: Badan Pusat Statistik Kota Bandung. Retrieved from https://bandungkota.bps.go.id/stat ictable/2018/07/06/147/jumlah-

Posyandu-di-kota-bandung2017.html

Eka, P. A. 2011. Ilmu Kesehatan Masyarakat Untuk Kebidanan Holistik (Integrasi Community Oriented ke Family Oriented). Yogyakarta: Nuha Medika

Hariani, S., \& Elytha, F. (2016). Artikel Penelitian Analisis Kebijakan Program Bina Keluarga Balita ( BKB ) Holistik Terintegrasi Dengan Posyandu dan PAUD di Kota Sawahlunto Tahun 2016. 8(1), 138-144.

Kemenkes, \& POKJANAL. (2012). Kurikulum dan Modul Pelatihan Kader Posyandu. Jakarta. Retrieved from https://www.slideshare.net/andromed apahlevi/91736007-

pedomanbaruPosyandu

Kemenkes RI. (2011). Pedoman Umum

Pelaksanaan Posyandu. Jakarta. Retrieved from http://promkes.kemkes.go.id/ped oman-umum-pengelolaanPosyandu

Kemenkes RI. (2018). Strategi Pemerintah Menurunkan AKI AKB Dan Harapan Terhadap Prognas Dalam Akreditasi RS. Jakarta. Retrieved from https://bulelengkab.go.id/assets/i nstansikab/101/bankdata/strategipemeritah-menurunkan-aki-akbakreditasi-rs-2-33.pdf

Kemenkes RI. (2019). Profil Kesehatan 2018 (2019).pdf. (R. Kurniawan, Ed.) (2nd ed.). Jakarta. Retrieved from

https://pusdatin.kemkes.go.id/res ources/download/pusdatin/profilkesehatanindonesia/PROFIL_KESEHATA N_2018_1.pdf

Kurnia. R. 2019. Pedoman Pelaksanaan Posyandu, Kesehatan Masyarakat Desa Dan Kelurahan.

Masturoh, I., \& Nauri, A. T. (2018). Metodologi Penelitian Kesehatan. Jakarta : Kementerian Kesehatan Republik Indonesia.

Nazri, C., Yamazaki, C., Kameo, S., Herawati, D. M. D., Sekarwana, N., Raksanagara, A., \& Koyama, H. (2016). Factors influencing mother's participation in Posyandu for improving nutritional status of children under-five in Aceh Utara district, Aceh province, Indonesia. $B M C$ Public Health, 16(1), 1-9. https://doi.org/10.1186/s12889016-2732-7 
Oktiawati A, Erna J, dan Regina N. 2016. Buku Pedoman Pelaksanaan Posyandu.

Roykhana, D., Nur, N., Husodo, B. T., Masyarakat, F. K., \& Diponegoro, U. (2018). FaktorFaktor Yang Berhubungan Dengan Evaluasi Program Deteksi Dini Tumbuh Kembang Balita Di Taman Posyandu Puskesmas Lamongan. Jurnal Kesehatan Masyarakat (eJournal), 6(1), 724-733.

Sahanggamu, P. D., Purnomosari, L., \& Dillon, D. (2017). Information exposure and growth monitoring favour child nutrition in rural Indonesia. Asia Pacific Journal of Clinical Nutrition, 26(2), 313316.

https://doi.org/10.6133/apjen.012 016.09

Sengkey, S. W., \& Pangemanan, G. D. K. J. M. (2015). Analisis Kinerja Kader Posyandu di Puskesmas Paniki Kota Manado Performance Analysis of Cadres Posyandu in Puskesmas Paniki Manado. Jikmu, 5(2b), 491-502.

Setiawan, A., \& Christiani, Y. (2018). Pos Pelayanan Terpadu (Posyandu) As A CommunityBased Program in Indonesia: An Exploratory Study. Jurnal Keperawatan Indonesia, 21(3), 150-158.

https://doi.org/10.7454/jki.v21i3. 600
Sugiyono. (2012). Metode Penelitian Kombinasi (Mixed Methods). Jogjakarta:

Alfabeta.

Swarjana I Ketut. 2016. Keperawatan Kesehatan Komunitas. Yogyakarta: Pustaka Pelajar.

Umasangaji, M. I. (2016). Partisipasi Masyarakat Pada Program Pos Pelayanan Terpadu (Posyandu) Di Desa Waitina Kecamatan Mangoli Timur. Jurnal Holistik, 18, 22-1. https://ejournal.unsrat.ac.id/index .php/holistik/article/view/13085

WHO. (2014). Trends in Maternal Mortality: 1990 to 2013. WHO Library Cataloguing-inPublication Data.

Windiarto, T., Huda, Y. Al, Santoso, A. D., Nugroho, S., Latifah, S., Solih, R., ... Rahmawatiningsih, A. (2018). Profil Anak Indonesia. (D. Romadhon, I. M. Surbakti, M. T. Nuryetty, W. Winarsih, A. Apriyanto, H. Rangkuti, ... A. P. Raharjo, Eds.). Jakarta: Kementerian Pemberdayaan Perempuan dan Perlindungan Anak (KPPPA). Retrieved from https://www.kemenpppa.go.id/lib /uploads/list/74d38-buku-pai2018.pdf

Zed, M. (2014). Metode Penelitian Kepustakaan. Jakarta: Yayasan Obor Indonesia. 